\title{
A new species of the spider genus Hippasa (Araneae: Lycosidae) from Yonagunijima Is., the Yaeyama Isls., Japan
}

\author{
Akio Tanikawa \\ Laboratory of Biodiversity Science, School of Agriculture and Life Sciences, \\ The University of Tokyo, 1-1-1, Yayoi, Bunkyo-ku, Tokyo, 113-8657 Japan \\ E-mail:dp7a-tnkw@j.asahi-net.or.jp
}

\begin{abstract}
A new lycosid species, Hippasa babai, is described using the specimens from Yonagunijima Is., which can be distinguished from $H$. holmerae Thorell 1895 by short male papal tibia as well as broad and thick projection of epigynum.
\end{abstract}

Key words - Hippasa babai, new species, Lycosidae, Yonagunijima, Okinawa, Japan.

The spiders of the genus Hippasa are interesting lycosid members because they make funnel webs resembling those of agelenid spiders (Fig. 1). 35 species of the genus Hippasa have been described from the old world (Platnick 2006), but no species are found in Japan. Through the spider survey in Yonagunijima Is., made by Yuki G. Baba and me, several specimens of Hippasa were obtained. Yonagunijima Is. is located near Taiwan where Hippasa holmerae Thorell 1895 has been recorded. Close examination revealed that the species is new to science, so I describe it in this paper under the name Hippasa babai.

Holotype and paratypes designated in this paper are deposited in the collection of the Department of Zoology, National Science Museum, Tokyo (NSMT). All measurements are given in mm. Following abbreviations are used in this paper; AER, anterior eye row; MER, median eye row; PER, posterior eye row.

I wish to express my heartfelt thanks to Dr. Tadashi Miyashita, the University of Tokyo, for his critical reading of the manuscript of this paper. I am deeply indebted to Mr. Yuki G. Baba, the University of Tokyo, for offering the specimens used in this study.

\section{Description \\ Family Lycosidae Sundevall 1833 Genus Hippasa Simon 1885 \\ [Japanese name: Tana-ami-komorigumo-zoku] \\ Hippasa babai new species \\ [Japanese name: Baba-komori-gumo]}

(Figs. 1-6)

Type series. Holotype and paratypes were collected by A. Tanikawa in Yonagunijima Is. Okinawa Pref., Japan. Holotype: $\delta^{\lambda}, 19-\mathrm{V}-2005$, Sonai (NSMT-Ar 5928; collected as a young spider, became adult male after raring on 1-VII-
2005). Paratypes: $3 \jmath^{3} 3$ 우, same data as holotype (NSMT-Ar 5929-5934; of these, $30^{7}$ and 1 우 were collected as young spiders, became adult males on 1, 14, 20-VII-2005 and female on 9-VII-2005 respectively); 2ㅇ, 22-VI-2004, Kubura-bari (NSMT-Ar 5935-5936).

Other specimens examined. All the specimens were collected in Yonagunijima Is.; 4우, same data as holotype, collected as young spiders, became adult females after raring on 25-VI (3우) and 14-VII-2005 (1우) respectively. 1우, 29-II2004, Kubura-bari, Y. G. Baba leg.; 3 우 22-VI-2004, same locality, A. Tanikawa leg.

Description. Coloration and markings. Female and male as shown in Figs. 2-3. Carapace light brown mottled with dark brown. Dorsum of abdomen dark brown with light colored markings. When alive, both carapace and abdomen greenish.

Measurements. Based on the holotype $\delta$ and paratype 1 우 (NSMT-Ar 5932), measurements in parentheses indicate the range among type series. Body o 7.00 (6.77-7.31), 우7.67 (7.67-9.00) long. Carapace 82.97 (2.97-3.28), 우3.23 (3.23$3.84)$ long; 32.17 (2.17-2.37), 우2.37 (2.37-2.80) wide. Length of legs [male/female; tarsus + metatarsus + tibia + patella + femur $=$ total]: I, $1.73+2.77+2.32+1.18$ $+2.86=10.86 / 1.48+3.10+2.00+1.24+2.67=$ 10.49 ; II, $1.64+2.73+2.27+1.18+2.82=$ $10.64 / 1.38+2.10+1.90+1.19+2.62=9.19$; III, $1.55+2.91+2.18+1.05+2.73=10.42 / 1.24+2.24$ $+1.81+1.05+2.57=8.91$; IV, $2.09+4.32+3.00$ $+1.14+3.41=13.96 / 1.62+3.57+2.62+1.14+$ $3.24=12.19$. Abdomen ${ }^{7} 3.88$ (3.52-4.05), ㅇ⒋36 (4.095.06) long; ð1.96 (1.95-1.96), 우2.45 (2.23-3.18) wide.

Female and male. Carapace longer than wide [length/width $31.37 \quad(1.37-1.42)$, +91.37 (1.34-1.43)]. PER procurved, PER wider than MER [PER/MER ${ }^{\top} 1.50$ (1.501.54), o1.51 (1.49-1.54)], AER wider than MER 

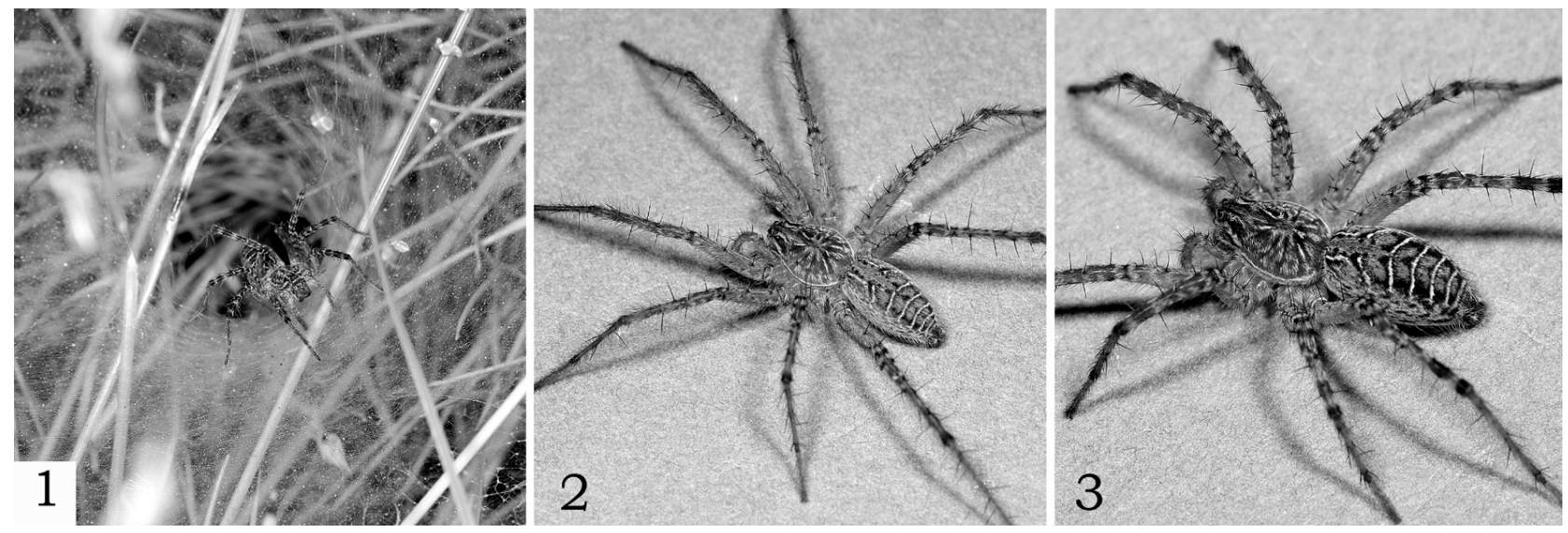

Figs. 1-3. Hippasa babai new species - 1, female on its web; 2, male (holotype, NSMT-Ar 5928); 3, female (paratype, NSMT-Ar 5932).

[AER/MER ð1.22 (1.21-1.23), + 1.23 (1.20-1.29)]. Fang furrow of chelicera with 3 teeth on both anterior and posterior margins. Labium wider than long [length/width ${ }^{\top} 0.82$ (0.79-0.89), +0.77 (0.74-0.83)]. Sternum longer than wide [length/width ${ }^{3} 1.13$ (1.12-1.16), ㅇ⒈14 (1.13-1.15)]. Length of leg I/length of carapace 33.66 (3.29-3.66), 우3.25 (2.65-
3.25). Male palp (Fig. 6): terminal apophysis curved anticlockwise. Abdomen longer than wide [length/width $\sigma^{7}$ 1.98 (1.80-2.07), 우1.78 (1.57-1.85)]. Epigynum with broad and thick tongue-like projection (Fig. 4), which is not entirely covered with hairs.

Remarks. The present new species closely resembles
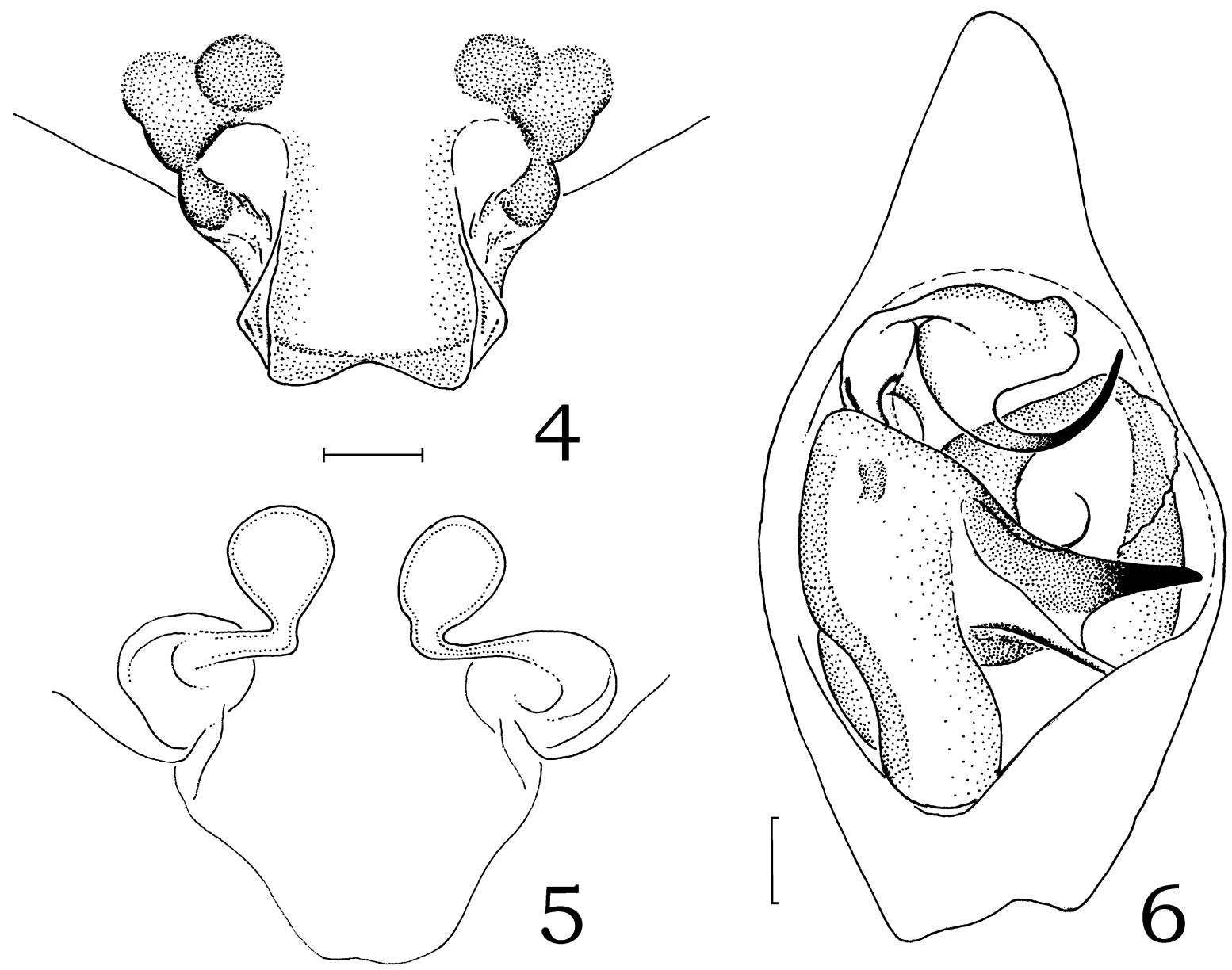

Figs. 4-6. Hippasa babai new species - 4, epigynum, ventral view (paratype, NSMT-Ar 5932); 5, same, dorsal view (paratype, NSMT-Ar 5932); 6, male palp, ventral view (holotype, NSMT-Ar 5928). (Scales: $0.1 \mathrm{~mm}$.) 
Hippasa holmerae Thorell 1895. By examining the syntypes of $H$. holmerae from Burma preserved in the Natural History Museum, London (BM1895.9.21.731-2, BM1895.9.21.733-50), I found that $H$. babai can be distinguished from $H$. holmerae by the following points. The ratio of the length of male palpal tibia to that of tarsus is smaller in babai than in holmerae ( $t$-test: $t=-7.42, d f=6$, $p=0.003$; Table 1$)$. The projection of epigynum is not entirely covered with hairs and broad and thick in babai, but covered with many hairs and narrow and thin in holmerae.

Distribution. Japan (Yonagunijima Is. of the Yaeyama Isls.).

Etymology. The specific name is dedicated to Mr. Yuki G. Baba, the University of Tokyo, who found this spider in Yonagunijima Is. for the first time.

Notes. Hippasa babai makes a funnel web on the short grasslands (Fig. 1) near the seashore. The spider is lurking in the retreat during daytime, but waiting at the entrance of the retreat at night. A mother spider attaches a cocoon to its spinnerets and holds spiderlings on its back like other lycosid spiders. A mother spider with a cocoon or spiderlings is always found in the retreat. Although $H$. babai has been found only in Yonagunijima Is. up to the
Table 1. The ratio of the length of male palpal tibia to that of tarsus in Hippasa holmerae Thorell 1895 and $H$. babai new species.

\begin{tabular}{cccc}
\hline Species & $\mathrm{N}$ & Range & Mean \pm SD \\
\hline H. holmerae & 4 & $0.88^{-} 0.96$ & $0.92 \pm 0.038$ \\
H. babai & 4 & $0.68^{-} 0.76$ & $0.73 \pm 0.036$ \\
\hline
\end{tabular}

present, more surveys are necessary in similar habitats in other islands.

\section{References}

Platnick, N. I. 2006. The world spider catalog, version 7.0. http://research.amnh.org/entomology/spiders/catalog/INTRO1.html Simon, E. 1885. Matériaux pour servir à la faune arachnologiques de 1'Asie méridionale. I. Arachnides recuellis à Wagra-Karoor près Gundacul, district de Bellary par M. M. Chaper. II. Arachnides recuellis à Ramnad, district de Madura par M. l'abbé Fabre. Bull. Soc. Zool. France 10: 1-39. (not seen)

Sundevall, J. C. 1833. Svenska spindlarnes beskrifning. Fortsättning Och Slut. Kongl. Svenska Vet. Ak. Handl. 1832: 172-272. (not seen)

Thorell, T. 1895. Descriptive Catalogue of the Spiders of Burma. British Museum, London, pp. 1-406.

Received August 7, 2006 / Accepted September 21, 2006 